\title{
Kajian Ergonomi di Sentra Persiapan BCCT: Menggugah Minat Baca-Tulis Anak Usia Dini Melalui Penataan Lingkungan Belajar yang Ergonomis
}

\author{
Laily Hidayati \\ STAI Al Hikmah Tuban \\ lailykusturayu@gmail.com
}

\begin{abstract}
Humans influence and are influenced by their environment.

That rule is fully accepted in the study of behavioral science or psychology. Thoughts, feelings, behaviors, and tendencies to act can "change" a situation, and can "changed" because of a situation. Ergonomics is the study of the relationship between humans and their environment, in order to improve the quality of these relationships so as to produce positive situations for humans, as well as positive for their environment. This conceptual writing wants to try to apply the study and the results of ergonomics studies into the practice of early childhood learning, by taking a learning approach that is closely related to environmental structuring, namely a center and circle based learning approach, also known as a Beyond Center and Circle Time (BCCT). Which is one of the centers of learning in the BCCT approach is the preparation center. That is the center for early childhood learning environments arranged in such a way that supports the achievement of the purpose of preparing early childhood to master the ability to read, write, and count. This paper wants to integrate the principles of environmental management of the preparation center, with the psychological fact that effective environmental management can really affect human performance, in this case the achievement of early childhood development in read, write, and count preparation. So that it is expected that the
\end{abstract}


efforts of early childhood education institutions to prepare well the tasks of early childhood development can be increased to the optimal level..

Keywords: ergonomics, BCCT, preparation center.

\section{PENDAHULUAN}

Untuk mencapai hasil pembelajaran yang optimal, banyak cara dan pendekatan yang diterapkan dalam dunia pendidikan, termasuk pendidikan anak usia dini. Persoalan pemberian materi membaca menulis dan berhitung yang ramai diperbincangkan oleh masyarakat karena pro kontra tentang terlalu dininya usia anak untuk menerima pembelajaran tersebut sebab belum siapnya mental anak, menuntut peneliti dan pemerhati pendidikan untuk menemukan pendekatan paling ramah yang jauh dari pemaksaan atau eksploitasi usia dini dalam penyiapan kemampuan membaca, menulis, dan berhitung. Karena diakui atau tidak, perkembangan teknologi dan gaya hidup yang sangat cepat, menuntut manusia untuk menyesuaikan diri dengan tugas-tugas kecakapan hidup sehari-hari, termasuk dalam hal literasi. Pun demikian dunia pendidikan seharusnya menemukan terobosan-terobosan yang dapat memenuhi standar tuntutan era digital namun tetap memperhatikan keseimbangan soSial emosional anak usia dini sebagai pebelajar.

Ergonomi bukanlah kajian baru dalam ilmu perilaku, yang lahir karena ingin menjawab tuntutan bagaimana potensi manusia dapat tergali secara optimal, dalam hal pekerjaan misalnya, namun tetap memperhatikan keterbatasan daya-daya biologis dan psikologis yang dimiliki manusia tersebut. Ergonomi menemukan fakta-fakta bahwa penataan lingkungan kerja tertentu dapat membuat manusia mencapai hasil kerja yang lebih mudah, lebih cepat, dan lebih sehat. Di sisi lain, menghindarkan manusia dari gangguan-gangguan fisik seperti otot kaku dan pinggul pegal, mental seperti kejenuhan dan stress. Hasil kajian tersebut rupanya tak hanya diterapkan dalam dunia kerja atau industri, namun semakin ke belakang, merambah juga dunia pendidikan. Mulai banyak dilaporkan hasil penelitian tentang pengaruh penataan lingkungan belajar terhadap proses dan hasil belajar siswa, atau pengaruh penataan lingkungan belajar terhadap kinerja pendidik dalam tugas-tugas kependidikannya. 
Tulisan ini merupakan tulisan konsepsional yang ingin melihat kemungkinan-kemungkinan yang dapat direncanakan, tentang aplikasi kajian-kajian ergonomi dalam praktik pembelajaran anak usia dini, secara khusus dalam praktik pembelajaran yang menggunakan pendekatan sentra dan lingkaran atau BCCT sebagai salah satu pendekatan yang dikenal banyak digunakan di lembaga-lembaga pendidikan anak usia dini yang penerapannya sangat memperhatikan segi penataan lingkungan belajar.

\section{PEMBAHASAN}

\section{Pendekatan Belajar Anak Usia Dini Berbasis Sentra dan Lingkaran}

Beyond Center and Circle Times (BCCT) adalah suatu metode pengajaran untuk anak usia dini yang dikembangkan berdasarkan kajian teoritik dan pengalaman empiric (Litbang dan Team Guru. Kelompok Bermain R.A. Istiqlal Jakarta). Metode ini merupakan pengembangan dari metode Montessori Heigh Scope dan Pegglo Emilia. Metode ini dikembangkan oleh Creative Centre for Childhood Research and Training (CCCRT) Florida USA selama lebih dari 33 tahun baik untuk anak normal maupun untuk anak yang berkebutuhan khusus. Ciri-ciri dari metode BCCT adalah: (1) Pembelajaran berpusat pada anak (2) Menempatkan setting lingkungan bermain sebagai pijakan awal yang penting (3) Memberikan dukungan penuh kepada setiap anak untuk aktif, Kreatif, dan berani mengambil keputusan sendiri. Terdapat (empat) tahap pijakan pengalaman bermain yang bermutu: (1) pijakan lingkungan bermain (2) Pijakan sebelum bermain (3) Pijakan saat bermain dan (4) Pijakan setelah bermain. Peran guru sebagai fasilitator, motivator dan evaluator, kegiatan anak berpusat di sentra-sentra yang berfungsi sebagai pusat minat, memiliki standar prosedur operasional yang baku, pemberian pijakan sebelum dan setelah anak bermain dilakukan dalam posisi duduk melingkar. Sentra-sentra tersebut di sekolahsekolah di Indonesia telah diadaptasi sedemikian rupa, yang meliputi: sentra persiapan, sentra bermain peran, sentra pembangunan atau balok, sentra sains, sentra imtaq, sentra bahan cair, serta sentra seni. (http://digilib.uinsby.ac.id/7313/2/bab.\%20ii.pdf, diakses pada 26 Februari 2019, 23:10 WIB) 
Metode BCCT ditujukan untuk merangsang seluruh aspek kecerdasan anak (kecerdasan jamak) melalui bermain yang terarah. Metode BCCT juga menciptakan setting pembelajaran yang merangsang anak untuk aktif, kreatif dan berpikir dengan menggali pengalamannya sendiri (bukan sekedar mengikuti perintah, meniru, dan menghafal). Metode BCCT dimulai dengan memahami perkembangan anak usia dini. Selain itu BCCT menggunakan beberapa teori dari para pakar pendidikan anak usia dini. Metode BCCT juga memahami konsep bermain pada anak sehingga dalam pelaksanaannya, semua kegiatan yang dilakukan adalah bermain yang diarahkan dan diiringi dengan muatan pengajaran. Tujuannya memberikan pengajaran melalui pengalaman pada anak pada saat bermain, sehingga anak menemukan ilmu tanpa tekanan dan dapat menerimanya sebagai hasil dari pengalaman bermain.

Menurut Depdiknas (2006), prinsip pendekatan sentra dan lingkaran, yaitu:

a. Keseluruhan proses pembelajarannya berlandaskan pada teori dan pengalaman empirik.

b. Setiap proses pembelajaran harus ditujukan untuk merangsang seluruh aspek kecerdasan anak (kecerdasan jamak) melalui bermain yang terencana dan terarah serta dukungan pendidik (guru/kader/pamong) dalam bentuk 4 jenis pijakan.

c. Menempatkan penataan lingkungan main sebagai pijakan awal yang merangsang anak untuk aktif, kreatif, dan terus berpikir dengan menggali pengalamannya sendiri.

d. Mempersyaratkan pendidik (guru/kader/pamong) dan pengelola program untuk mengikuti pelatihan sebelum menerapkan metode ini.

e. Melibatkan orang tua dan keluarga sebagai satu kesatuan proses pembelajaran untuk mendukung kegiatan anak di rumah.

f. Menggunakan standar operasional yang baku dalam proses pembelajaran, yaitu meliputi: (1) pendidik (guru/kader/pamong) menata lingkungan main sebagai pijakan lingkungan yang mendukung perkembangan anak; (2) ada pendidik (guru/kader/pamong) yang bertugas menyambut kedatangan anak dan mempersilahkan untuk bermain bebas dulu (waktu untuk penyesuaian); (3) semua anak mengikuti main pembukaan dengan 
bimbingan pendidik (guru/kader/pamong); (4) pendidik (guru/kader/pamong) memberi waktu kepada anak untuk ke kamar kecil dan minum secara bergiliran/pembiasaan antri; (5) anak-anak masuk ke kelompok masing-masing dengan dibimbing oleh pendidik (guru/kader/pamong) ybs; (6) pendidik (guru/kader/pamong) duduk bersama anak didik dengan membentuk lingkaran untuk memberikan pijakan pengalaman sebelum main; (7) pendidik (guru/kader/pamong) memberi waktu yang cukup kepada anak untuk melakukan kegiatan di sentra main yang disiapkan sesuai jadwal hari itu; (8) selama anak berada di sentra, secara bergilir pendidik (guru/kader/pamong) memberi pijakan kepada setiap anak; (9) pendidik (guru/kader/pamong) bersama anakanak membereskan peralatan dan tempat main; (10) pendidik (guru/kader/pamong) memberi waktu kepada anak untuk ke kamar kecil dan minum secara bergiliran; (11) pendidik (guru/kader/pamong) duduk bersama anak didik dengan membentuk lingkaran untuk memberikan pijakan pengalaman setelah main; (12) pendidik (guru/kader/pamong) bersama anak-anak makan bekal yang dibawanya (tidak dalam posisi istirahat); (13) kegiatan penutup; (14) anak-anak pulang secara bergilir; (15) pendidik (guru/kader/pamong) membereskan tempat dan merapikan/mencek catatan-catatan dan kelengkapan administrasi; (16) pendidik guru/kader/pamong) melakukan diskusi evaluasi hari ini dan rencana esok hari; (17) pendidik (guru/kader/pamong) pulang.

Sentra persiapan adalah sentra yang digunakan untuk kegiatan membaca dan menulis (Ditjen PLPS, Depdiknas, 2004). Sentra persiapan ditujukan pada ranah perkembangan kognisi (berpikir) dan motorik halus. Bahan yang disediakan di sentra ini lebih menunjang munculnya keaksaraan dari pada pembelajaran yang diberikan oleh guru. Tugas guru di sentra persiapan adalah menyiapkan lingkungan, mengamati tingkat perkembangan anak, dan menggunakan pertanyaan untuk membawa anak ke tingkat berpikir yang lebih tinggi. Penataan di sentra harus menyediakan kesempatan untuk percakapan satu persatu antara guru dengan anak serta di antara anak. Jumlah bahan yang disediakan merupakan macam-macam kegiatan atau tempat kerja ditata sesuai dengan tingkat perkembangan dan pengalaman anak saat ini. 
Setiap tempat bermain dirancang untuk sejumlah anak sesuai dengan jumlah kursi atau jumlah bahan (misal, dua pasang penjepit) jumlah tempat kerja dihitung dengan menggunakan rumus dari Prescott dan Krit Chevsky. Rumus ini menyarankan dua setengah tempat bermain untuk setiap anak di sentra. Satu kelompok dengan 10 anak akan membutuhkan 25 tempat. Guru juga harus menyampaikan kegiatan yang diarahkan langsung maupun yang tidak langsung. Bila satu guru saja di sentra, maka seharusnya tidak ada kegiatan yang diarahkan langsung. Tetapi jika ada dua guru, satu guru dapat memperhatikan kepada kegiatan yang harus diarahkan langsung dan guru yang satu lagi dapat berpindah di antara anak-anak yang menyusun kegiatan sendiri. Terlalu banyak kegiatan yang harus diarahkan langsung guru akan "terikat" pada kegiatan itu dan tidak dapat memberi pijakan pada anak di kegiatan lain. Waktu percakapan satu persatu dengan anak selama di sentra mendukung pertumbuhan bahasa dan bagian terpenting dari pengalaman di sentra persiapan. (http://digilib.uinsby.ac.id/7313/2/bab.\%20ii.pdf, diakses pada 26 Februari 2019, 23:10 WIB).

Pijakan lingkungan munculnya keaksaraan adalah: guru mengatur lingkungan munculnya keaksaraan sehingga setiap saat anak masuk ke dalam ruangan tersebut. Anak datang dan berkumpul di tempat yang ditentukan untuk membuka saat lingkaran. Pada saat ini anak-anak belajar tentang bahan dan kegiatan baru. Arahan ini memberi anak informasi tentang apa yang guru harapkan dari anak di setiap kegiatan. Mencontohkan kegiatan bahan yang tepat dan menyampaikan aturan memakainya secara ringkas dan jelas, merupakan strategi penting agar membantu anak dalam kemandirian pada penggunaan bahan. Guru meminta anak memperhatikan beberapa banyak kegiatan yang mereka selesaikan selama di sentra. Sebelum selesai saat lingkaran, anak diberi lima langkah petunjuk, memilih sebuah kegiatan, menyelesaikan kegiatan tersebut, menunjukkan kepada guru apa yang sudah dikerjakan, merapikan kegiatan tersebut dan memilih kegiatan lainnya. Hal-hal penting yang diingat untuk keberhasilan sentra persiapan adalah: menyediakan tempat kerja yang cukup, memilih bahan yang dapat digunakan dengan beragam cara dan beragam tingkat perkembangan, mencontohkan membaca dan menulis sebagai pengalaman yang menyenangkan, menerima semua usaha yang anak buat menuju membaca dan menulis, anak belajar huruf dan kata pertama yang bermakna untuk mereka, menyediakan banyak jenis dan 
tingkat buku sepanjang sentra, memberi waktu anak untuk bicara dengan satu sama lain dan guru.

\section{Ergonomi Dan Pengaruhnya Pada Perilaku Manusia}

Kata ergonomi berasal dari bahasa Yunani yaitu 'ergo' yang berarti kerja dan 'nomos' yang berarti hukum. Ergonomi dapat didefinisikan sebagai studi tentang aspek-aspek manusia dalam lingkungan kerjanya yang ditinjau secara anatomi, fisiologi, psikologi, engineering, manajemen dan desain/ perancangan. Ergonomi berkenaan pula dengan optimasi, efisiensi, kesehatan, keselamatan dan kenyamanan di tempat kerja, di rumah, dan tempat rekreasi. Di dalam ergonomi dibutuhkan studi tentang sistem di mana manusia, fasilitas kerja dan lingkungannya saling berinteraksi dengan tujuan utama yaitu menyesuaikan suasana kerja dengan manusianya. Ergonomi disebut juga sebagai "Human Factors" (Nurmianto, 1996). Ergonomi terkadang disebut juga dengan human factor engineering, human centered design atau occupational engineering. Ergonomi adalah disiplin ilmu yang mempelajari pemahaman interaksi manusia dengan elemen-elemen sistem lainnya, serta mengimplementasikan teori, prinsip, data dan metode untuk merancang guna mengoptimalkan kemaslahatan manusia dan performansi sistem secara keseluruhan. (http://arifindustri.lecture.ub.ac.id/opinions/opergonomi. Diakses pada 26 Februari 2019, 23:16 WIB)

Kajian ergonomi yang berhubungan dengan aspek ukuran fisik manusia dan bertujuan untuk mendapatkan rancangan peralatan, produk atau tempat kerja yang ergonomis dengan memperhatikan dimensi tubuh target pengguna dikenal dengan antropometri. Dalam antropometri terdapat dua jenis dimensi ukuran yaitu struktural (statis) dan fungsional (dinamis) Herjanto (2008) dalam Izzhati (2015). Dimensi struktural untuk mengukur dimensi tubuh manusia pada kondisi tetap (statis) sedangkan dimensi fungsional adalah untuk mengukur dimensi tubuh ketika sedang mengadakan kegiatan. Ergonomi dapat berperan pula sebagai desain pekerjaan pada suatu organisasi, misalnya: penentuan jumlah jam istirahat, pemilihan jadwal pergantian waktu kerja (shift kerja), meningkatkan variasi pekerjaan, dan lain-lain. Di samping itu ergonomi juga memberikan peranan penting dalam meningkatkan faktor keselamatan dan kesehatan kerja seperti yang ditunjukkan pada gambar 2.1, misalnya: desain suatu sistem kerja untuk mengurangi rasa nyeri dan ngilu pada sistem kerangka dan otot manusia, desain stasiun kerja 
untuk alat peraga manusia visual (visual display unit station) (Nurmianto, 1996).

Menurut Santoso (2013) ergonomi merupakan satu upaya dalam bentuk ilmu, 5 teknologi, dan seni untuk menyerasikan peralatan, mesin pekerjaan, sistem, organisasi dan lingkungan dengan kemampuan, kebolehan dan batasan manusia sehingga tercapai suatu kondisi dan lingkungan yang sehat, aman, nyaman, efisien dan produktif, melalui pemanfaatan tubuh manusia secara maksimal dan optimal. Agar tercapai kondisi seperti itu, seharusnya peralatan dan lingkungan dikondisisikan sesuai dengan alat. Untuk keperluan perancangan alat dan lingkungan diperlukan nilai standar ergonomis yang dibuat disesuaikan dengan kemampuan dan batasan manusia. Sesuai dengan pengertian ergonomi, prinsip penting ergonomi yang selalu digunakan adalah prinsip fitting the task to the man, yang berarti harus disesuaikan dengan kemampuan dan keterbatasan manusia. Tujuan pembelajaran ergonomi adalah Untuk menganalisa, merancang dan mengimplementasikan sistem yang lebih manusiawi (system humanization), dengan memperhatikan ukuran tubuh, kemampuan, kapabilitas dan batasan (dimension, ability, capability and limitation) serta kebutuhan dan keinginan (need and wish) dari manusia yang berinteraksi dengan lingkungan kerjanya (work environment) baik fisik maupun sosial.

Lingkup ergonomi berdasarkan skala sistemnya meliputi dua hal, yaitu: ergonomi mikro, yang merupakan lingkup yang berkaitan dengan sistem kerja fisik yang melibatkan faktor manusia, pekerjaannya, metode/prosedur kerjanya, bahan/hasil kerjanya, alat bantu kerjanya dan lingkungan kerja fisiknya. Serta ergonomi makro yang merupakan lingkup yang berkaitan dengan sistem kerja sosio-teknik lebih luas yang menambahkan faktor psikologi dan kognitif manusia, lingkungan kerja organisasional, lingkungan sosial yang lebih luas (sosiologi, etnografi, civilization, religi).

Lingkup ergonomi berdasarkan konsentrasinya meliputi: physical ergonomics, yaitu lingkup yang berkaitan dengan anatomi, antropometri, sistem muskuloskeletal, kinesiologi, biomekanika, sistem metabolisme dan fisiologi yang berhubungan dengan kerja fisik. Termasuk studi postur kerja, gerakan kerja, tata letak ruang kerja, beban kerja fisik, kerja berulang, regangan/tegangan terakumulasi, kelelahan, cedera kerja dan kecelakaan kerja. Selain itu juga terdapat cognitive ergonomics, yaitu lingkup yang berkaitan dengan psikologi, 
penginderaan, sistem syaraf, hormon dan kognitif mencakup persepsi, memori, berpikir, respon motorik yang berhubungan dengan kerja mental. Termasuk studi pembelajaran, pengambilan keputusan, beban kerja mental, human reliability, stress kerja, human error. Yang terakhir adalah organizational ergonomics, yaitu lingkup yang berkaitan dengan struktur organisasi, kebijakan organisasi, proses organisasi, budaya organisasi yang berhubungan dengan kerja antar manusia dalam sistem sosio-teknik. Termasuk studi komunikasi, manajemen sumber daya, desain pekerjaan, tim kerja, desain partisipatori/kolaborasi/kooperasi, ergonomi komunitas. (http://arifindustri.lecture.ub.ac.id/opinions/op-ergonomi/2 Diakses pada 26 Februari 2019, 23:16 WIB).

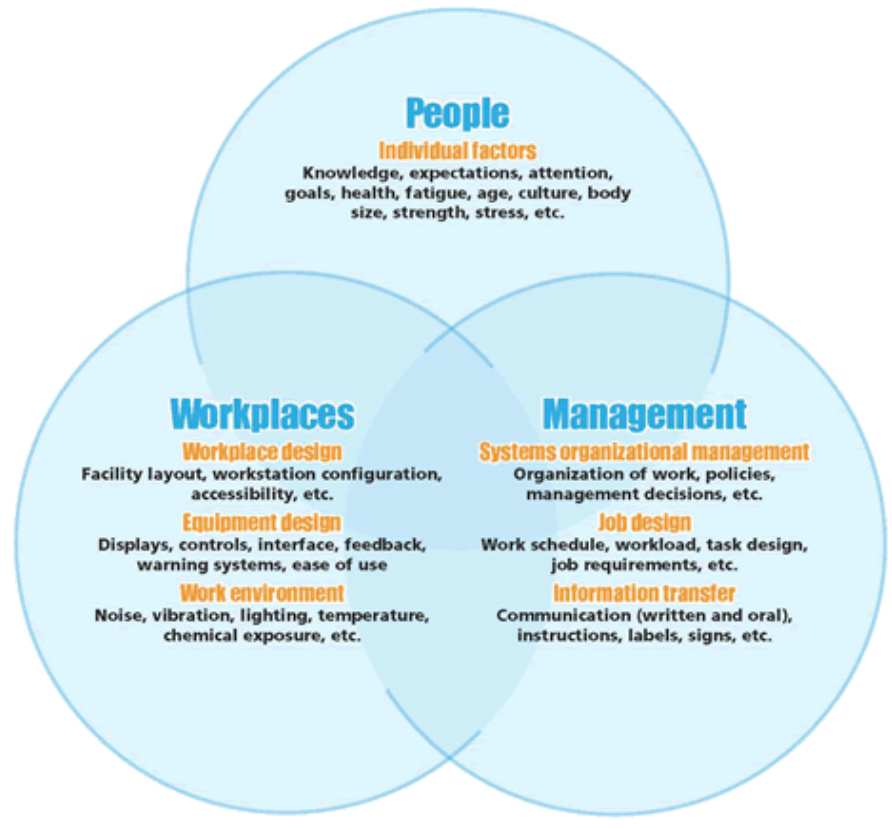

Gambar 1.

Hubungan antara manusia, lingkungan kerja, dan manajemen Sumber:http://arifindustri.lecture.ub.ac.id/opinions/opergonomi

Bidang penelitian ilmu ergonomi meliputi: Anatomi dan Anthropometri beberapa bidang sebagai berikut: ortopedik, kinesiologi dan biomekanik, fisiologi dan metabolisme, lingkungan kerja: fisik dan sosial, sistem syaraf dan kognitif, studi kerja: postur, gerakan dan ekonomi gerakan, studi beban kerja: fisik dan mental, sosiologi dan psikologi industri, rekayasa sistem kerja dan metode kerja, desain produk, 
desain peralatan dan alat bantu kerja, desain interface dan control, desain ruang kerja dan tata letak, pembakuan dan spesialisasi kerja, pengayaan dan perluasan kerja, penjadwalan kerja dan istirahat, penugasan dan rotasi kerja, produktivitas dan pengukuran kinerja, kesehatan dan keselamatan kerja, work related musculoskeletal disordered: overuse disordered, repetitive stress/strain disordered dan cummulative trauma disordered, serta human reliability dan human error. (http://arifindustri.lecture.ub.ac.id/opinions/opergonomi/3 . Diakses pada 26 Februari 2019, 23:17)

\section{Sentra Persiapan Yang Ergonomis Pada Pembelajaran Anak Usia Dini}

Sebagaimana dijelaskan pada bagian sebelumnya, sentra persiapan adalah sentra yang digunakan untuk kegiatan membaca dan menulis (Ditjen PLPS, Depdiknas, 2004). Sentra persiapan ditujukan pada ranah perkembangan kognisi (berpikir) dan motorik halus. Bahan yang disediakan di sentra ini lebih menunjang munculnya keaksaraan dari pada pembelajaran yang diberikan oleh guru. Tugas guru di sentra persiapan adalah menyiapkan lingkungan, mengamati tingkat perkembangan anak, dan menggunakan pertanyaan untuk membawa anak ke tingkat berpikir yang lebih tinggi. Penataan di sentra harus menyediakan kesempatan untuk percakapan satu persatu antara guru dengan anak serta di antara anak. Jumlah bahan yang disediakan merupakan macam-macam kegiatan atau tempat kerja ditata sesuai dengan tingkat perkembangan dan pengalaman anak saat ini.

Penataan ruang sentra persiapan harus ditata sedemikian rupa sehingga nyaman sekaligus mampu merangsang rasa ingin tahu siswa untuk mengeksplorasi benda-benda atau stimulus belajar serta media yang sengaja ditata di situ untuk "menjebak" siswa sehingga tertarik dan tumbuh keinginan belajar. Karakteristik anak usia dini yang memang imajinatif, aktif, dan mudah penasaran, akan sangat mudah dikondisikan dengan stimulus-stimulus yang kaya dengan unsur-unsur membaca, menulis, dan berhitung. Misalnya gambar atau poster huruf, angka, binatang, buah, sayur, benda sekitar, alat-alat, serta stimulus lain yang berhubungan dengan aktivitas persiapan calistung. Anak-anak "didekatkan" atau "dibuat dekat" dengan stimulus sehingga respon yang diinginkan pun tercapai, yaitu tergugahnya rasa ingin tahu siswa. Berikut adalah beberapa contoh penataan lingkungan 
sentra persiapan yang ergonomis, sebelum lebih lanjut tulisan ini akan menguraikan prinsip-prinsip ergonomi.

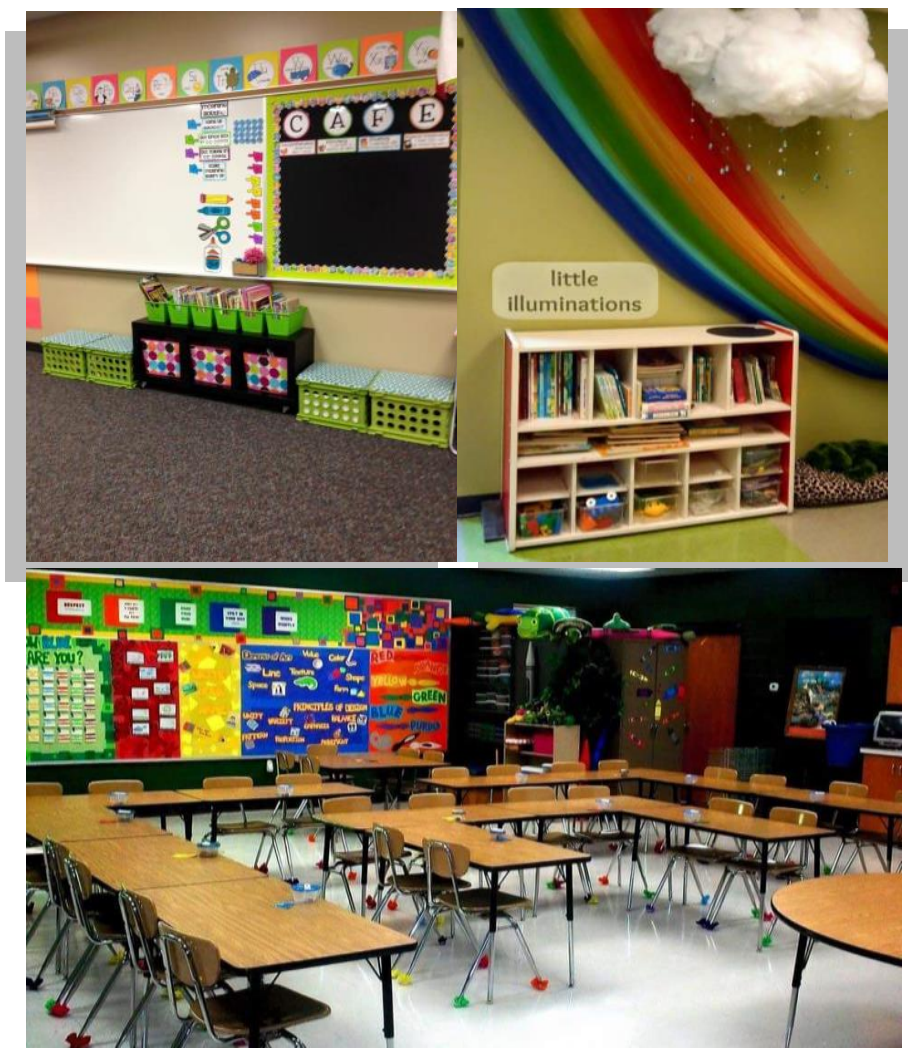

Gambar 2.

Contoh penataan sentra persiapan dengan stimulus buku-buku bacaan

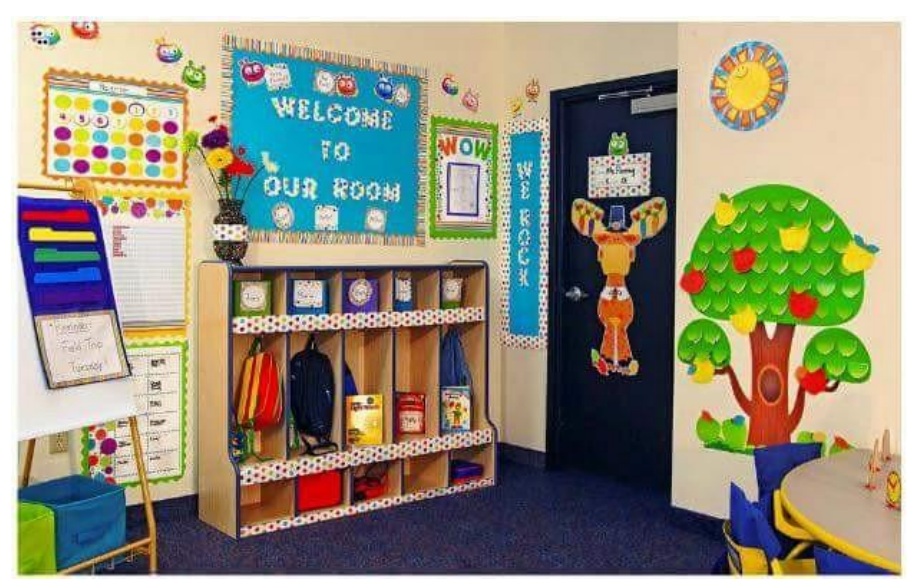




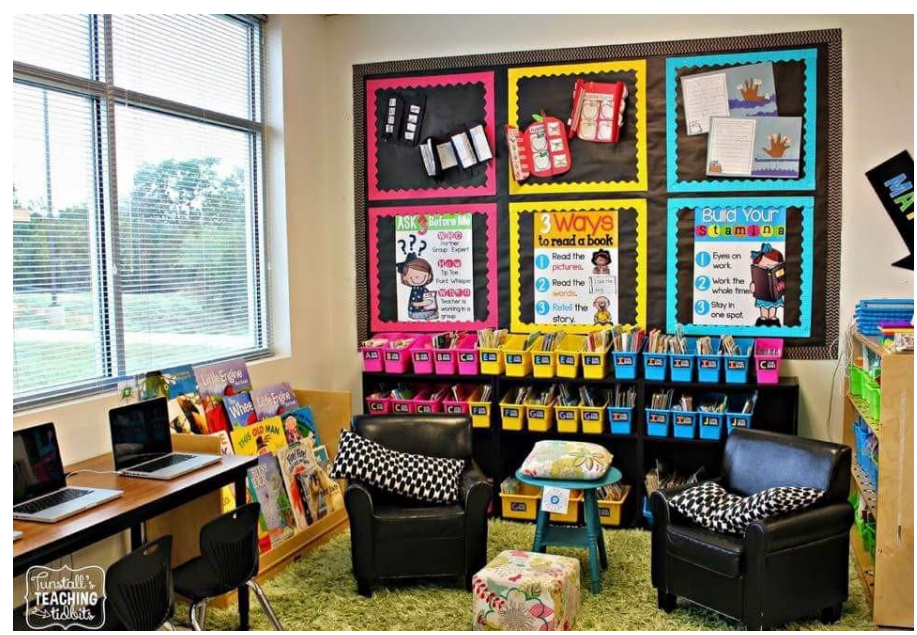

Gambar 3.

Contoh penataan sentra dengan stimulus angka dan huruf untuk pengenalan literasi

Memahami prinsip ergonomi akan mempermudah evaluasi setiap tugas atau pekerjaan meskipun ilmu pengetahuan dalam ergonomi terus mengalami kemajuan dan teknologi yang digunakan dalam pekerjaan tersebut terus berubah. Prinsip ergonomi adalah pedoman dalam menerapkan ergonomi di tempat kerja. Menurut Baiduri dalam diktat kuliah ergonomi terdapat 12 prinsip ergonomi, yaitu sebagai berikut: (http://ergonomi-fit.blogspot.com/2011/12/tujuan-danprinsip-ergonomi.html. Diakses pada 4 Maret 2019, 22:04 WIB)

a. Bekerja dalam posisi atau postur normal.

b. Mengurangi beban berlebihan.

c. Menempatkan peralatan agar selalu berada dalam jangkauan.

d. Bekerja sesuai dengan ketinggian dimensi tubuh.

e. Mengurangi gerakan berulang dan berlebihan.

f. Minimalisasikan gerakan statis.

g. Minimalisasikan titik beban.

h. Mencakup jarak ruang.

i. Menciptakan lingkungan kerja yang nyaman.

j. Melakukan gerakan, olah raga, dan peregangan saat bekerja. 
k. Membuat agar display dan contoh mudah dimengerti.

Terdapat setidaknya tiga prinsip BCCT yang harus diperhatikan yang mana ketiganya berkaitan erat dengan prinsip ergonomis dalam lingkup pembelajaran, yaitu: a) Keseluruhan proses pembelajarannya berlandaskan pada teori dan pengalaman empirik, b) Setiap proses pembelajaran harus ditujukan untuk merangsang seluruh aspek kecerdasan anak (kecerdasan jamak) melalui bermain yang terencana dan terarah serta dukungan pendidik (guru/kader/pamong) dalam bentuk 4 jenis pijakan, $c$ ) Menempatkan penataan lingkungan main sebagai pijakan awal yang merangsang anak untuk aktif, kreatif, dan terus berpikir dengan menggali pengalamannya sendiri. Dari ketiga prinsip di atas, prinsip penataan lingkungan main adalah prinsip yang perlu mendapat perhatian dalam penerapan kajian ergonomi pembelajaran anak usia dini. Jika hal tersebut dianalisis dengan 11 prinsip ergonomi di atas, penerapannya dalam lingkungan belajar anak usia dini yaitu penataan ruangan sentra persiapan dapat diuraikan sebagai berikut:

a. Siswa belajar dalam posisi atau postur normal. Implikasinya, pengelola pendidikan harus memperhatikan posisi tubuh siswa ketika beraktivitas di dalam kelas. Misalnya dalam penataan kursi dan meja, haruslah disesuaikan dengan tinggi badan anak. Atau dalam kegiatan mewarnai, posisi meja yang terlalu rendah, akan menyebabkan siswa kurang nyaman sehingga cepat lelah dan siswa tidak mampu menyelesaikan tugas belajarnya.

b. Siswa belajar tanpa terbebani baik secara fisik maupun mental. Implikasinya, pengelola pendidikan harus meminimalisir beban yang biasanya dirasakan oleh siswa secara fisik, misalnya membawa tas yang melebihi berat ideal yang mampu dibawanya. Atau beban mental misalnya tekanan atau tuntutan berlebih dari lingkungan sekitarnya.

c. Menempatkan peralatan agar selalu berada dalam jangkauan. Implikasinya, penataan lingkungan main di sentra BCCT harus mudah dijangkau oleh siswa. Bukan disimpan dalam etalasi yang terkunci, bukan pula tergantung pada posisi yang sulit terjangkau oleh siswa.

d. Bekerja sesuai dengan ketinggian dimensi tubuh. Sama seperti poin sebelumnya, penempatan media belajar yang ditata untuk memberikan stimulus kepada siswa, dalam 
hal ini minat baca tulis siswa, harus berada pada jangkauan siswa.

e. Mengurangi gerakan berulang dan berlebihan. Implikasinya, penetapan petunjuk belajar atau SOP yang dibuat oleh pengelola lembaga haruslah efektif dan efisien bagi siswa sehingga meminimalisir kelelahan atau terbuangnya waktu tanpa belajar.

f. Minimalisasikan gerakan statis. Implikasinya, pengelola lembaga harus memantau waktu yang digunakan oleh siswa yang melibatkan gerakan-gerakan fisiknya agar tidak sampai kurang atau sebaliknya, bergerak berlebihan. Siswa harus tetap dapat menyalurkan energi fisiknya melalui gerakan sehingga tidak statis yang dapat menyebabkan kelelahan dan berkurangnya konsentrasi.

g. Minimalisasikan titik beban. Implikasinya, kegiatan menarik minat baca siswa dikondisikan bukan sebagai beban kerja akan tetapi sebagai sesuai yang menyenangkan dan tumbuh dari keinginan atau minat individual siswa. Secara tidak langsung, penyediaan buku-buku atau bahan bacaan dengan gambar-gambar yang menarik, diperlukan guna untuk menumbuhkan ketertarikan siswa sehingga memberikan respon tanpa paksaan, yaitu dalam hal ini tumbuhnya minat baca.

h. Mencakup jarak ruang. Implikasinya, pengelola harus pula memperhatikan jarak antar stimulus minat baca yang satu dengan yang lain. Misalnya pengelola menempel tulisan berbunyi "BOLA" pada box yang berisi bola. Atau menempel tulisan berbunyi "BUKU" pada rak buku.

i. Menciptakan lingkungan kerja yang nyaman. Implikasinya, secara keseluruhan, ruangan sentra persiapan haruslah nyaman, baik dari segi pencahayaan, ventilasi udara, kelembapan, bebas dari benda yang membahayakan, dll.

j. Melakukan gerakan, olah raga, dan peregangan saat bekerja. Implikasinya, pengelola harus memperhatikan pembuatan jadwal kegiatan di ruang sentra persiapan, bukan membiarkan siswa beraktivitas tanpa panduan dari pendidik. Misalnya, membuka sesi pelajaran dengan bernyanyi dan memperagakan, tepuk-tepuk, dan selanjutnya aktivitas kegiatan inti diselingi dengan ice breaking untuk perenggangan otot. 
k. Membuat agar display dan contoh mudah dimengerti. Implikasinya, pengelola haruslah memilih media atau sumber belajar yang telah terstandar efektif dan efisien, sehingga mudah dimengerti oleh siswa sesuai dengan tahap usianya. Misalnya sebagaimana disebutkan di atas, mendekatkan tempelan kata "BOLA" dengan benda bola.

\section{SIMPULAN}

Memahami prinsip ergonomi akan mempermudah evaluasi setiap tugas atau pekerjaan dalam konteks ini mempermudah pengelola lembaga pendidikan anak usia dini dalam mengelola dan mengevaluasi pencapaian tugas-tugas perkembangan siswa, khususnya tugas dalam sentra persiapan calistung yang memang dikhususkan untuk persiapan dasar membaca, menulis, dan berhitung. Semua bahan, media, display dan alat belajar haruslah sesuai dengan tujuan pencapaian perkembangan sentra itu, mudah dijangkau, aman, sekaligus menarik perhatian. Di lain sisi, pengelola pun harus memastikan penerapan prinsip-prinsip tersebut haruslah dalam pengawasan dan praktik terstandar yang disebut dengan SOP atau Standar Operasional Prosedur yang perumusannya harus memerhatikan keseluruhan aspek perkembangan siswa, baik fisik maupun mentalnya. Wallaahu a'lam bish-shawaab.

\section{DAFTAR PUSTAKA}

Litbang dan Team Guru. Kelompok Bermain R.A. Istiqlal Jakarta, "Metode Pembelajaran Anak Usia Dini Melalui Pendekatan Sentra dan Saat Lingkaran". Jl. Taman Wijaya Kusuma Jakarta, 10710.

Ditjen PLPS, Depdiknas. 2004. "Lebih Jauh tentang ABC dan dan CCCRT, Menulis Namaku: Munculnya Keaksaraan”. Jakarta Timur: Sekolah AI-Falah.

Nurmianto, Eko. 1996. Ergonomi: Konsep Dasar dan Aplikasinya. Surabaya: Guna Widya

Santoso, G. 2013. Ergonomi Terapan. Jakarta: Prestasi Pustakaraya 
LAILY HIDAYATI

Ergonomi dan Human Factor Engineering. http://arifindustri.lecture.ub.ac.id/opinions/op-ergonomi Diakses pada 26 Februari 2019, 22:51 WIB.

Tujuan dan Prinsip Ergonomi http://ergonomifit.blogspot.com/2011/12/tujuan-dan-prinsipergonomi.html (diakses pada 4 Maret 2019, 22:04 WIB)

Depdiknas. 2006. Pedoman Penerapan Pendekatan "Beyond Centers And Circle Time (Bcct)" (Pendekatan Sentra Dan Lingkaran) dalam Pendidikan Anak Usia Dini. Jakarta. 